\title{
KONTRIBUSI PENDAPATAN PENGUPAS BAWANG MERAH TERHADAP PENDAPATAN KELUARGA
}

\section{CONTRIBUTION OF SHALLOT PEELER REVENUE TO FAMILY INCOME}

\author{
Muhammad Thamrin*, Desi Novita**, Uswatun Hasanah* \\ *Program Studi Agribisnis Fakultas Pertanian UMSU \\ **Program Studi Fakutas Pertanian UISU \\ Email :mhdthamrin@umsu.ac.id
}

\begin{abstract}
Abstrak
Penelitian ini bertujuan untuk mengetahui seberapa besar kontribusi pendapatan pengupas bawang merah terhadap pendapatan keluarga.Teknik pengambilan Sampel dalam penelitian ini menggunakan Simple Random Sampling. Dengan total populasi124 orangdiambil sampel penelitian ini sebanyak 25 orang. Adapun metode analisis data yang digunakan dalam penelitian ini adalah dengan menggunakan analisis deskriptif.Hasil penelitian menunjukkan kontribusi pendapatan pengupas bawang merah sebesar 9,55\%, yang berarti bahwa pendapatan pengupas bawang merah masih tergolong rendah terhadap pendapatan keluarga.
\end{abstract}

Kata Kunci: Kontribusi, Pendapatan, Pengupas Bawang Merah

\begin{abstract}
This study aims to determine how much the contribution of onion peeler income to family income. The sampling technique in this study used Simple Random Sampling. With a total population of 124 people, the sample of this study was 25 people. The data analysis method used in this study is to use descriptive analysis. The results showed that the contribution of shallot peeler income was $9.55 \%$, which means that the income of shallot peeler was still relatively low on family income.
\end{abstract}

Keywords: Contribution, Income, Shallot Peeler

\section{A. PENDAHULUAN}

Sektor pertanian merupakan salah satu sektor yang mempunyai peranan penting dalam meningkatkan perkembangan ekonomi Indonesia.Hal ini dikarenakan sektor pertanian adalah sumber mata pencaharian utama dari sebagian besar masyarakat Indonesia. Sektor pertanian melalui komoditas yang dihasilkannya mempunyai potensi besar dalam meningkatkan pendapatan masyarakat petani di Indonesia

Tanaman bawang merah (Alium ascolanum L.) termasuk salah satu tanaman sayuran umbi multiguna. Bawang merah adalah salah satu komoditas unggulan dibeberapa daerah di Indonesia, yang digunakan sebagai bumbu masakan dan memilki kandungan beberapa zat yang bermanfaat bagi kesehatan, dan khasiatnya sebagai zat anti kanker dan pengganti antibiotik, penurunan tekanan darah, kolestrol serta penurunan kadar gula darah. Menurut penelitian, bawang merah ,mengandung kalsium, fosfor, zat besi, karbohidrat, vitamin seperti A dan $\mathrm{C}^{1}$.

Tanaman bawang merah berasal dari daerah Asia Selatan yaitu didaerah sekitar India, sampai Palestina.Negara-negara di Eropa Barat, Eropa Timur, dan Spanyol.Mengenal bawang merah pada abad ke delapan.Dari eropa Barat, Eropa Timur, dan Asia Tenggara.Penyebaran ini tampaknya berhubungan dengan pemburuan rempah-rempah oleh bangsa Eropa ke wilayah
Timur jauh yang kemudian berlanjut dengan penduduk Kolonial di wilayah Indonesia ${ }^{2}$.

Berdasarkan data Badan Pusat Penelitian Statistik penghasil bawang merah di Provinsi Sumatera Utara adalah Kabupaten Karo, Simalungun, Tapanuli Selatan, Tapanuli Utara, Dairi, Humbang Hasundutan, Toba Sampsir, Samosir dan Mandailing Natal. Produksi bawang merah Sumatera Utara tahun 2013 sebesar 8.305 ton sedangkan pada tahun 2014 produksinya 7.810 ton. Data tersebut menunjukkan bahwa produksi bawang merah pada tahun 2014 mengalami penurunan sebesar 495 ton $(5,96 \%)$.

Bekerja adalah melakukan pekerjaan dengan maksud memperoleh atau membantu memperoleh pendapatan atau keuntungan dan lamanya bekerja paling sedikit satu jam secara terus menerus dalam seminggu yang lalu (termasuk pekerja keluarga tanpa upah yang membantu dalam suatu usaha atau kegiatan ekonomi).

Pada umumnya motivasi kerja kebanyakan tenaga kerja wanita adalah membantu menghidupi keluarga.Akan tetapi, motivasi itu juga mempunyai makna khusus karena memungkinkan memiliki otonomi keuangan, agar tidak selalu tergantung kepada pendapatan suami.Beberapa motivasi wanita bekerja pada industri rumah tangga adalah karena suami tidak bekerja, pendapatan rumah tangga kurang, mengisi waktu luang, ingin mencari uang sendiri, dan ingin mencari pengalaman ${ }^{3}$. 
Dalam membantu perekonomian keluarga banyak hal yang dilakukan oleh seorang istri, mulai dari bekerja hingga membuka usaha sendiri tentunya dengan tujuan sebagai penopang ekonomi keluarga. Sementara Ibu rumah tangga dengan usia paruh baya yang tidak memiliki modal yang mendukung dan skill (kemampuan) memilih pekerjaan yang tidak menuntut keahlian tertentu dalam bekerja.

Salah satu pekerjaan yang dipilih yaitu sebagai pengupas bawang. Setelah menyelesaikan pekerjaan rumah tangga kala siang hingga sore hari puluhan ibu-ibu rumah tangga tersebut berada dipekarangan rumah mereka untuk mengupas bawang. Alasannya daripada diam jenuh di rumah tanpa penghasilan mewakili mayoritas masyarakat di lingkungan sekitar, selain tentunya himpitan dapur dan biaya anak-anak mereka sekolah ${ }^{4}$.

Pekerjaan sampingan mengupas bawang merah disini yaitu tidak dikupas sampai bersih seperti halnya untuk memasak, melainkan hanya membersihkan kulit bawang yang terlihat kering dan membuang akar-akarnya saja.

Upah pengupas bawang sendiri tergantung dari berapa kg dalam setiap isi karung yang dikupas tersebut dan mendapat imbalan bawang dari hasil kupasan mereka sendiri untuk kebutuhan dapur, terkadang pula ibu-ibu rumah tangga juga menjual kembali bawang hasil dari kupasan yang ibu rumah tangga peroleh setiap harinya. Tekad masingmasing yang akan meningkatkan penghasilan mereka, kadang ada juga yang satu hari bisa menyelesaikan 1 hingga 2 karung.Pemasok setiap hari akan mengambil hasil kupasan bawang yang telah selesai dan akan berlanjut dengan menyediakan karung bawang lainnya. Pembayaran akan mereka peroleh setiap bulan nya, Hasil kupasan bawang akan dialokasikan untuk memenuhi orderan. Permintaan ini akan terus berlanjut selama pemasok mampu memberikan pelayanan yang baik dan memuaskan.

Kontribusi berasal dari bahasa inggris yait u contribute, contribution, maknanya adalah keikutsertaan, keterlibatan, melibatkan diri maupun sumbangan.. Kontribusi dalam pengertian sebagai tindakan yaitu berupa perilaku yang dilakukan oleh individu yang kemudian memberikan dampak baik positif maupun negative terhadap pihak lain. Dengan kontribusi berarti individu tersebut juga berusaha meningkatkan efisiensi dan efektifitas hidupnya.

Dengan kontribusi berarti individu tersebut juga berusaha meningkatkan efisiensi dan efektifitas hidupnya. Hal ini dilakukan dengan cara menajamkan posisi perannya, sesuatu yang kemudian menjadi bidang spesialis,agar lebih tepat sesuai kompetensi. Kontribusi dapat diberikan dalam berbagai bidang yaitu pemikiran, kepemimpinan, profesionalisme, finansial ${ }^{5}$.

Tingginya kontribusi wanita terhadap pendapatan keluarganya menunjukkan bahwa wanita mempunyai keinginan yang tinggi dalam membantu suami dan anggota keluarga yang lainnya dalam memenuhi kebutuhan hidup keluarga. Ditambah lagi beban hidup yang semakin hari semakin meningkat, membuat wanita mau tidak mau harus lebih giat lagi dalam berusahatani.

Hal ini tentu saja mendorong lebih cepatnya proses pembangunan nasional seutuhnya. Kontribusinya bagi pendapatan rumahtangga dalam banyak hal bersifat tidak langsung karena berkat pekerjaan yang dilakukan tersebut maka anggota lain dalam keluarga (rumahtangganya) dapat melakukan kegiatan yang secara langsung menghasilkan uang untuk digunakan bagi keperluan rumahtangga ${ }^{6}$.

Banyak wanita yang awalnya hanya melakukan pekerjaan rumah saja, kini banyak yang memutuskan untuk bekerja. Hal itu dipengaruhi oleh beberapa faktor, salah satunya adalahpeningkatan akan kebutuhan hidup yang semakin mahal danpendapatan yang didapatkan oleh suami terbilang kurang sehingga mengakibatkanmereka memiliki keinginanuntuk ikut membantu dalam hal pendapatan demi memenuhi kebutuhan hidup dan sekaligus untuk meningkatkan kesejahteraan keluarganya.

Pendapatan anak merupakan bagian dari total pemasukan keluarga. Pendapatan anak didapatkan apabila anak sudah memilki pekerjaan. Pendapatan anak biasa dihitung bersama menjadi pendapatan total keluarga untuk melihat sejauh mana seorang anak yang menjadi tanggungan keluarga dapat membantu memenuhi kebutuhan keluarganya.

Pendapatan anak biasa dihitung dari hasil pekerjaannya dan masih belum memiliki keluarga atau belum menikah Pendapatan keluarga diartikan sebagai pendapatan yang diperoleh seluruh anggota keluarga, baik suami, istri, maupun anak.Pendapatan keluarga petani akan bertambah jika kedua belah pihak (suami dan istri) bekerja, sehingga disini diperlukan peran istri (wanita tani) yang mana besar-kecilnya pendapatan istri akan mengakibatkan tinggi-rendahnya pendapatan keluarga tersebut ${ }^{7}$.

Pendapatan keluarga dapat berasal dari lebih dari satu pendapatan, sumber pendapatan yang beragam tersebut dapat terjadi karena anggota keluarga yang bekerja melakukan lebih dari satu pekerjaan atau masing-masing anggota keluarga mempunyai kegiatan yang berbeda antara yang satu dengan yang lainnya ${ }^{8}$.

Rumusan masalah dalam penelitian adalah, Bagaimana karakteristik sosial ekonomi, seberapa 


\section{KONTRIBUSI PENDAPATAN PENGUPAS BAWANG MERAH}

besar pendapatan pelaku dan seberapa besar kontribusi pendapatan pengupas bawang merah terhadap pendapatan keluarga.

\section{B. METODE PENELITIAN \\ Metode Penelitian}

Dalam Penelitian ini peneliti terjun langsung ke objek atau informan yang diteliti dengan melakukan penjelajahan dan mengajukan beberapa pertanyaan terkait dengan permasalahan yang diambil oleh peneliti terhadap informan.

\section{Metode Penentuan Lokasi Penelitian}

Penelitian ini dilaksanakan di Kelurahan Tanjung Mulia Hilir, Kecamatan Medan Deli Kota Medan.Lokasi penelitian ini dilakukan secara sengaja (purposive sampling).

Metode Penarikan Sampel

Metode yang digunakan dalam pengambilan sampel dalam penelitian ini adalah Simple Random Sampling. Pengambilan sampel secara random atau acak dengan memberikan peluang yang sama bagi setiap unsur atau anggota populasi untuk dipilih menjadi anggota sampel ${ }^{9}$.

Populasi adalah keseluruhan objek yang menjadi sasaran penelitian, sedangkan sampel diartikan sebagai bagian dari populasi yang menjadi objek penelitian. Populasi dalam penelitian ini adalah seluruh pengupas bawang di Kelurahan Tanjung Mulia Hilir yang berjumlah 124 orang. Dari jumlah populasi sebanyak 124 orang diambil sebesar $20 \%$ sebagai sampel sehingga di peroleh 25 orang.

Penentuan sampel dilakukan secara acak sederhana (simple random sampling), ,penentuan pengambilan sampel apabila kurang dari 100 lebih baik diambil semua, jika jumlah subjeknya lebih dari 100 orang maka dapat di ambil antara 10-15\% atau $20-25 \%{ }^{10}$.

\section{Metode Pengumpulan Data}

Data yang diambil dari dari data primer dan data sekunder, data primer yaitu data-data yang diperoleh secara langsung dari sumber asli (tanpa perantara).Data sekunder yaitu data penunjang yang berkaitan dengan penelitian yang diperoleh dari berbagai sumber atau instansi seperti BPS dan data perusahaan yang berhubungan dengan penelitian ini.

\section{Metode Analisis Data}

Untuk menjawab permasalahan pertama mengenai bentuk kegiatan yang dilakukan oleh ibu rumah tangga dalam hal membantu meningkatkan pendapatan keluarga ialah menggunakan analisis deskriptif dengan menggunakan tabulasi sederhana berdasarkan data primer yang diperoleh dilokasi penelitian.

Untuk menganalisis masalah yang kedua mengenai pendapatan pelaku pengupas bawang digunakan analisis pendapatan dengan menggunakan rumus sebagai berikut:

Keterangan:

$$
\mathrm{TC}=\mathrm{FC}+\mathrm{VC}
$$

$$
\begin{aligned}
& \mathrm{TC}=\text { Total Cost } / \text { Total biaya } \\
& \mathrm{FC}=\text { Fixed } \text { Cost } / \text { Biaya tetap } \\
& \mathrm{VC}=\text { Variabel Cost/Biaya variabel }
\end{aligned}
$$

Penerimaan adalah perkalian antara produksi yang diperoleh dengan harga jual. Pernyataan ini dapat ditulis sebagai berikut:

$$
\mathrm{TR}=\mathrm{Py} . \mathrm{Y}
$$

Keterangan:

$$
\begin{gathered}
\mathrm{TR}=\text { Total Revenue } / \text { Total } \\
\text { penerimaan }(\mathrm{Rp}) \\
\mathrm{Py}=\text { Harga jual }(\mathrm{Rp}) \\
\mathrm{Y}=\text { Jumlah produksi }(\mathrm{kg})
\end{gathered}
$$

Pendapatan adalah selisih antara penerimaan dan total biaya. Pernyataan ini dapat ditulis sebagai berikut:

Keterangan

$$
\mathrm{Pd}=\mathrm{TR}-\mathrm{TC}
$$

$\mathrm{Pd}=$ Pendapatan Usaha ibu rumah tangga (Profit)

$\mathrm{TR}=$ Total Revenue (Penerimaan Total)

$\mathrm{TC}=$ Total $\operatorname{Cost}($ Biaya Total $)$

Permasalahan yang ketiga, dianalisis secara deskriptif yaitu dengan mengumpulkan seluruh data yang diperlukan untuk mengetahui besarnya kontribusi pengupas bawang terhadap total pendapatan keluarga. Dimana pendapatan keluarga adalah pendapatan pengupas bawang ditambah pendapatan keluarga (usaha keluarga).

$$
\mathbf{P}=\frac{Y i}{Y t} \mathbf{x} 100 \%
$$

Keterangan:

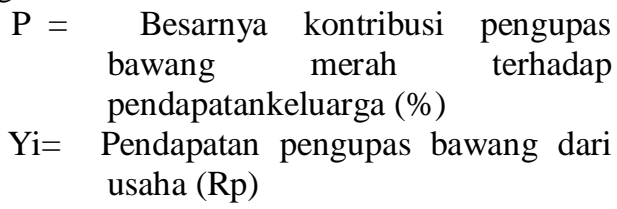

$\mathrm{Yt}=$ Total pendapatan keluarga $(\mathrm{Rp})$

Ada pun kategori atau ukuran besar kontribusi dapat di interpresentasikan sebagai berikut :
a) Rendah $=0 \%-33,3 \%$
b) Sedang $=33,4 \%-66,6 \%$
c) Tinggi $=66,7 \%-100 \%$.

\section{HASIL DAN PEMBAHASAN}

Karakteristik Sosial Ekonomi Responden Pengupas bawang

Dari hasil penelitian yang saya lakukan dapat di lihat Karakteristik Sosial Ekonomi Responden Ada 6 faktor sosial ekonomi yang akan saya jelaskan pada daerah penelitian tersebut yaitu umur, tingkat pendidikan, pengalaman bekerja, 
jumlah tanggungan, alasan memilih mengupas bawang dan pekerjaan suami.

\section{Umur}

Dari hasil sebaran kuisioner yang dilakukan kepada responden menunjukkan bahwa pada umumnya responden pengupas bawang berdasarkan umur 31-40 tahun dengan jumlah responden 5 orang (20\%), 41-50 tahun dengan jumlah responden 17 orang (68\%), umur 51-60 dengan jumlah responden 3 orang (12\%).

\section{Tingkat Pendidikan}

Dari hasil sebaran kuisioner yang dilakukan kepada responden menunjukkan bahwa tingkat pendidikan responden terbanyak adalah tingkat pendidikan dasar atau SMA / sederajat sekitar 48\% dan terendah Sekolah Dasar hanya sekitaran $12 \%$.

\section{Pengalaman Bekerja}

Dari hasil sebaran kuisioner yang dilakukan kepada responden menunjukkan bahwa pada umumnya responden memiliki pengalaman mengupas bawang diantara 1-5 tahun dengan jumlah responden 20 orang (80\%). Pengupas bawang yang memiliki pengalaman bekerja yang cukup lama yaitu yang memiliki pengalaman bekerja 6-10 tahun dengan jumlah responden 5 orang (20\%) umumnya memiliki pengetahuan yang lebih banyak dibandingkan pengupas yang baru saja menekuni usaha tersebut.

\section{Pengalaman Mengupas Bawang}

Dari hasil sebaran kuisioner yang dilakukan kepada responden menunjukkan bahwa pada umumnya responden memiliki pengalaman mengupas bawang diantara 1-5 tahun dengan jumlah responden 20 orang (80\%). Pengupas bawang yang memiliki pengalaman bekerja yang cukup lama yaitu yang memiliki pengalaman bekerja 6-10 tahun dengan jumlah responden 5 orang $(20 \%)$ umumnya memiliki pengetahuan yang lebih banyak dibandingkan pengupas yang baru saja menekuni usaha tersebut.

\section{Jumlah tanggungan}

Dari hasil sebaran kuisioner yang dilakukan kepada responden dari hasil penelitian pada sampel sebanyak 25 jiwa. Dapat diketahui bahwa jumlah tanggungan sampel yang paling banyak adalah 3 tanggungan sebanyak 8 jiwa dengan persentase $32 \%$ dan yang paling sedikit adalah yang tidak memiliki tanggungan yaitu sebanyak 2 jiwa dengan persentase $8 \%$. Hal ini menunjukan bahwa jumlah tanggungan pada responden pengupas bawang tidak banyak sehingga kemungkinan kebutuhan dan pengeluaran yang dilakukan responden tidak terlalu banyak.

\section{Alasan mengupas bawang}

Dari hasil sebaran kuisioner yang dilakukan kepada responden dari hasil penelitian diatas alasan semua responden memilih mengupas bawang karena ingin menambah pendapatan keluarga.
Diketahui bahwa pada sampel sebanyak 25 jiwa dengan persentase $100 \%$.

\section{Jenis pekerjaan suami responden}

Dari hasil sebaran kuisioner yang dilakukan kepada responden sebagian besar pekerjaan suami responden pengupas bawang bekerja sebagai Pegawai Swasta yaitudengam jumlah 9 jiwa dengan persentase (36\%) sedangkan yang bekerja sebagai Wiraswasta yaitu sebagai supir, pengusaha mebel, mebel yaitu sebanyak 6 jiwa (24\%) sedangkan penduduk yang bekerja sebagai Petani sebanyak 2 jiwa (8\%), buruh 3 jiwa (12\%) nelayan 1 jiwa (4\%), Security 1 jiwa (4\%) pedagang 2 jiwa $(8 \%)$ dan pengangguran 1 jiwa (4\%).Dapat kita ketahui bahwa sampel pengupas bawang menurut jenis pekerjaan suami lebih banyak bekerja sebagai Pegawai Swasta.

\section{Besar Pendapatan Pelaku Pengupas Bawang Merah di Kelurahan Tanjung Mulia Hilir Kecamatan Medan Deli. \\ Penerimaan}

Penerimaan diperoleh dengan melihat seberapa besar kuantitas suatu produk dikalikan dengan harga jual yang dikeluarkan.

Rata-rata responden Pengupas bawang mengupas 52,8 Kg/bulan dengan dihargai tiap $\mathrm{kg}$ nya $\mathrm{Rp} 150$. Dari hasil penelitian diperoleh upah pengupas bawang merah perbulan di peroleh ratarata sebesar Rp. 158.400 per bulan (20 hari). Ibu rumah tangga memperoleh upah pokok/imbalan berupa bawang merah yang sudah bersih yang diberikan kepada pemasok bawang diperoleh ratarata perbulan nya sebesar Rp. $5,86 \mathrm{~kg} / \mathrm{bulan}$ dan ibu rumah tangga tersebut menjual kembali bawang yang di peroleh kekonsumen dengan harga perkilonya rata-rata Rp. 25.000. Sehingga dari hasil penelitian saya, memperoleh penerimaan perbulan dengan rata-rata sebesar Rp. 304.900.

\section{Biaya Produksi}

Biaya produksi dalam pengupasan bawang merah ini mencakup biaya tetap dan biaya variabel. Rata-rata biaya produksi yang dikeluarkan pengupas bawang perhari produksi adalah sebesar Rp.4.978,32,

Pada proses produksi biaya rata-rata tetap yang dikeluarkan sampel pengupas bawang membeli alat-alat seperti Gunting, baskom kecil, ember besar dan timbangan.. Jadi Total Biaya ratarata tetap yang digunakan dalam proses produksi adalah Rp 3.698,32. Pada proses produksi biaya rata-rata variabel yang dikeluarkan sampel pengupas bawang para sampel membeli kebutuhan seperti Goni. Jadi Total Biaya rata-rata variable yang digunakan dalam proses produksi adalah Rp 1.280 . 


\section{KONTRIBUSI PENDAPATAN PENGUPAS BAWANG MERAH}

\section{Pendapatan}

Total penerimaan rata-rata adalah $\mathrm{Rp}$. 304.900 sedangkan total rata-rata biaya produksi adalah Rp. 4.978,32dan total Pendapatan rata-rata pengupas bawang merah perhari produksi adalah sebesar Rp. 299.921,67 /bulan.

\section{Kontribusi Pendapatan Pengupas Bawang Merah terhadap Pendapatan Keluarga}

Kontribusi merupakan hasil dari pembagian antara pendapatan pengupas bawang dibagi dengan pendapatan keluarga yang terdiri dari pendapatan suami, istri, anak adalah sebagai berikut

Kontribusi $=\frac{\text { pendapatan pengupas bawang }}{\text { total pendapatan keluarga }}$ X $100 \%$

Kontribusi $=\frac{299.921,67}{3.251,921} \times 100 \%=9,55 \%$

Dengan demikian maka dapat diambil kesimpulan bahwa kontribusi pengupas bawang merah dalam upaya meningkatkan pendapatan keluarga memeiliki Kontribusi Rendah, yaitu 9,55\% dan dari hasil penelitian yang saya lakukan dapat dilihat bahwa pengupasan bawang merah di Kelurahan Tanjung Mulia Hilir sangat membantu pendapatan rumah tangga responden dalam memenuhi kebutuhan keluarga responden yang di peroleh dari pendapatan pengupas bawang sebesar Rp. 299.921,67dibagikan dengan pendapatan total keluarga sebesar Rp 3.251,951dikalikan 100\% maka kontribusi $9,55 \%$.

Kontribusi dikatakan rendah karena ibu rumah tangga pada umumnya hanya mengupas bawang 1 sampai dengan 2 karung dalam sehari. Proses pengupasan bawang ini membutuhkan waktu yang lama, tidak memungkinkan untuk mereka mengambil sampai lebih dari 2 karung, karena disamping mereka mengupas bawang mereka juga harus mengurus rumah tangga nya pada pagi dan sore hari. Pekerjaan mengupas bawang yang dilakukan setiap harinya hanya sebagai pekerjaan sampingan, disamping mereka hanya menganggur dirumah dan berdiam diri tidak menghasilkan apa-apa mereka memilih untuk berpartisipasi dalam pengupasan bawang,Tetapi dalam membantu meningkatkan pendapatan keluarga sudah cukup membantu untuk meringankan beban suami, contohnya pemasukan uang jajan anak sekolah dan membeli bumbu masak setiap harinya.

Ibu rumah tangga mengupas bawang setiap hari mencapai 40-80 kg/hari nya. Disamping mereka mendapat upah mengupas $150 / \mathrm{kg}$, mereka juga mendapat upah pokok bawang/imbalan yang sudah bersih mencapai rata-rata $5-10 \mathrm{~kg} /$ bulan tergantung dari pada banyak nya yg dikupas(kg). Bawang yang mereka dapatkan akan dijual dengan harga Rp.25.000/kg.Terlalu banyak persedian bawang mereka didapur sehingga mereka menjual bawang tersebut, karena jika dibiarkan lama kelamaan bawang akan membusuk.

\section{KESIMPULAN DAN SARAN \\ Kesimpulan}

1. Karakteristik Sosial Ekonomi Responden Ada 6 faktor Sosial yaitu umur, tingkat pendidikan, pengalaman bekerja, jumlah tanggungan, alasan memilih mengupas bawang dan jenis pekerjaan suami responden.

2. Dari hasil penelitian diperoleh upah pengupas bawang merah perbulan di peroleh rata-rata sebesar Rp. 158.400/bulan. Ibu rumah tangga memperoleh upah pokok berupa bawang merah yang sudah bersih yang di beri kepada pemasok bawang diperoleh rata-rata perbulanya sebesar Rp.5,86 kg/bulan dan ibu rumah tangga tersebut menjual kembali bawang yang diperoleh kekonsumen dengan harga perkilonya rata-rata Rp.25.000. Sehingga penerimaan perbulan dengan rata-rata sebesar Rp.304.900. Total biaya per bulan sebesar Rp.4.978,33Pendapatan perbulan yang diterima pengupas bawang adalah sebesar Rp.299.921,67

3. Berdasarkan hasil penelitian, presentase kontribusi pengupas bawang merah terhadap total pendapatan keluarga adalah sebesar 9,55\%. Artinya kontribusi pendapatan pengupas bawang merahdi masih tergolong rendah. Namun pendapatan ini sudah dianggap sangat membantu perekonomian keluarga.

\section{DAFTAR PUSTAKA}

1. Purba, MC. 2016. http//repository.uma.ac.id. Diakses pada tanggal 20 Maret 2018.

2. Angso, 2016. http://dinsar.jambikota.go.id/inde x.php/2016/12/02/kerja sampinganibu-rumahtangga-pilih-kupas-bawang-dipasar-angso-duo/ diakses pada tanggal 27 Desember 2017.

3. Azhar, 2017. Kontribusi Pendapatan Perempuan Pengrajin Atap Nipah Terhadap Pendapatan Keluarga. Fakultas pertanian, Universitas Syiah Kuala.

4. Nauli,„Intan., 2017. Analisis Kontribusi koperasi terhadap kinerja petani, Fakultas Pertanian, Universitas Muhammadiyah Sumatera Utara.

5. Roni, 2016. Alokasi Waktu Kerja Dan Kontribusi Wanita Tani Dalam Meningkatkan Pendapatan Rumah tangga Pada Budidaya Rumput Laut, Jurusan/ Program Studi Agribisnis Fakultas Pertanian Universitas Halu Oleo Kendari. 
6. Gusmaniar, 2013.Kontribusi Pendapatan Wanita Peternak Kelinci Terhadap Total Pendapatan Keluarga:studi kasus di Kelurahan Salokaraja Kecamatan Lalabata Kabupaten Soppeng. Fakultas Peternakan, Universitas Hasanuddin. Makasar.

7. Ariyani, 2015. Kontribusi Usahatani Tembakau Terhadap Pendapatan Rumah Tangga, Fakultas Ekonomi, Universitas Negeri Yogyakarta.
8. Martin, 2016. http// scholar. Unand.ac.id. Diakses pada tanggal 20 Maret 2018.

9. Sugiyono, 2012.Metode Penelitian Bisnis. Alfabeta, CV. Bandung.

10. Arikunto, S.(2016). Prosedur Penelitian Suatu Pendekatan Praktik. Rineka Cipta. Jakarta 